\title{
ENKELE ASPEKTE IN VERBAND MET ONDERHOUDVOERING
}

\author{
L.J. FICK \\ DEPARTEMENT BEDRYFSIELKUNDE \\ UNIVERSITEIT VAN STELLENBOSCH
}

\begin{abstract}
SUMMARY
Research findings in the field of interviewing are systematically presented and some conclusions are drawn and suggestions made based on these findings.
\end{abstract}

Beach (1975, p.171) definieer onderhoudvoering as volg: "An interview is a conversation or verbal interaction, normally between two people, for a particular purpose". Die doel identifiseer gewoonlik die soorte onderhoude wat in 'n organisasie gevoer kan word. Byvoorbeeld, voorligtings-, raadgewings-, griewe-, meriete-, seleksie- en bedankingsonderhoud. In hierdie oorsig word daar spesifiek op die(seleksie-) keuringsonderhoud gekonsentreer.

Die doel in die geval van die seleksie-onderhoud is om paslike inligting van die applikant te bekom ten opsigte van vermoëns, bekwaamhede, kennis en persoonlikheids-eienskappe wat in 'n pos vereis word. Die doel is ook om inligting aangaande die pos en werksomstandighede aan die applikant te verskaf om hom in staat te stel om die besluit te neem of hy wel oor die vermoëns, belangstellings, en ander eienskappe beskik om die werk te doen en of hy bereid is om by die besondere organisasie te werk.

Die onderhoud is die oudste tegniek en ook dié voorspellertegniek wat die meeste in die praktyk vir die seleksie van personeel gebruik word. Dit verteenwoordig egter in sy tradisionele vorm 'n baie subjektiewe proses met 'n lae interbeoordelaarsbetroubaarheid en openbaar oor die algemeen swak voorspellingsgeldighede (Flippo, 1971; Miner en Miner, 1973 en Beach, 1975). Deur die jare is sekere stappe vir die voer van 'n onderhoud neergelê en sekere beginsels omlyn wat die grondslag vorm vir "betroubaarder en geldiger" onderhoudvoering, maar daar sal nie hier daarop ingegaan word nie. Daar sal eerder sommige van die belangrikste bevindings uit navorsingstudies puntsgewys opgesom word om die bruikbaarheid, betroubaarheid en algemene geldigheid van die onderhoud as voorspellertegniek soos wat dit normaalweg in die seleksiesituasie gebruik word, te evalueer. 
- $\quad$ 'n Onderhoudvoerder is redelik konsekwent in sy beoordeling van dieselfde applikant. As 'n onderhoudvoerder op 'n latere stadium weer 'n onderhoud met dieselfde applikant voer of na 'n opname van 'n vorige onderhoud luister, is hy geneig om dieselfde beoordelings te maak (Mayfield, 1964 en Carlson, Thayer, Mayfield en Peterson, 1971).

- $\quad$ As verskillende onderhoudvoerders gebruik word om 'n ongestruktureerde onderhoud met dieselfde applikante vir die vul van dieselfde pos te voer, kom hul tot verskillende gevolgtrekkings. Interbeoordelaarsbetroubaarheid is dus baie laag vir onderhoudvoerders (Mayfield, 1964; Schwab en Heneman, 1969; Valenzi en Andrews, 1973; Hollman, 1972 en Langdale en Weitz, 1973.) Vroeë navorsing deur Hollingworth (1922) demonstreer reeds die onbetroubaarheid van die beoordelings wat deur ervare onderhoudvoerders gemaak word. Wagner (1949) kom in sy omvattende oorsig tot die gevolgtrekking dat onderhoudresultate neig om onbetroubaar te wees en dat die geldigheid daarvan dus bevraagteken kan word. Latere oorsigte van die literatuur op die gebied deur Mayfield (1964), Ulrich en Trumbo (1965) en Webster (1964) lewer nie veel meer bemoedigende resultate ten opsigte van die onderhoud as seleksietegniek nie.

- Die houdings en vooroordele van onderhoudvoerders het 'n groot invloed op hul beoordelings (Mayfield, 1964 en Webster, 1964).

- Vooroordele word vroeg in die onderhoud gevorm (Webster, 1964) .

- $\quad$ Onderhoudvoorvoerders neig om 'n stereotipe beeld van 'n goeie kandidaat te vorm en vergelyk dan blykbaar alle applikante daarmee, (Webster, 1964; Hakel en Dunnette, 1968; Hakel, Dobmeyer en Dunnette, 1970, Hakel, Hollmann en Dunnette, 1970 en Hakel, Okinesorge en Dunnette, 1970).

- Onderhoudvoerders word skynbaar meer deur ongunstige as gunstige inligting beïnvloed. Hulle neig om na negatiewe inligting te soek. Navorsing toon verder dat onderhoudvoerders se besluite na aanleiding van addisionele inligting meer geredelik tot verwerping as tot aanvaarding van kandidate beïnvloed word. Onvoldoende gewig word aan positiewe inligting geheg (Webster, 1964; Mayfield, 1964; Mayfield en Carlson, 1966 en Hollmann, 1972). 
- $\quad$ Onderhoudvoerders neig om baie vroeg in 'n ongestruktureerde onderhoud tot die besluit te kom of hul die applikant in diens gaan neem of hom gaan verwerp (Mayfield 1964 en Mayfield en Carlson, 1966).

- Die hoeveelheid inligting aangaande die pos waaroor die onderhoudvoering beskik, beïnvloed ook sy besluit. Meer inligting lei tot hoër interbeoordelaarbetroubaarheid (Longdale en Weitz, 1973).

- Deur 'swak' kandidate voor 'goeie' kandidate te sien, lei tot 'n groter aantal gunstige "aanvaardings" as wat andersom die geval sou wees (Row, 1963). Wexley, Yukl, Kovacs en Sanders (1972) vind dat die kontras-effek die sterkste is, wanneer 'n onderhoud met 'n gemiddelde applikant voorafgegaan is deur onderhoude met twee hoogs aanneemlik of aanvaarbare applikante of twee minder geskikte kandidate.

- Daar is 'n konsekwente verskil tussen onderhoudvoerders ten opsigte van die totale aantal persone wat hul as aanvaarbaar beskou (Rowe, 1963).

- Gedurende 'n onderhoud waarin 'n applikant aanvaar word, praat die onderhoudvoerder die meeste en in 'n gunstiger toon as in 'n onderhoud waartydens 'n applikant verwerp word (Webster, 1964).

- Onderhoudvoerders oorweeg dikwels persoonlike voorkoms as die belangrikste dimensie ten spyte van die feit dat daar weinig bewyse is dat voorkoms enige verband met werksukses het (Carroll, 1969).

- Geskrewe feitelike inligting word egter deurgaans in die literatuur as meer belangrik as voorkoms in die beoordeling van applikante in 'n onderhoud beskou (Carlson, 1967; Carroll, 1969; Hakel, 1968 en Asher, 1970, (b)).

- $\quad$ Die onderhoud is 'n relatief ongeldige voorspeller van werkskriteria. (Trites, 1960; Mayfield, 1964; Ulrich en Trambo, 1965; Wright, 1969 en Beach, 1975).

Daar bestaan egter baie goeie bewys dat 'n mate van strukturering die betroubaarheid en geldigheid van die onderhoud merkwaardig verhoog. So bevind Schwab en Heneman (1969) byvoorbeeld dat bloot die strukturering wat deur die gebruik van 'n aansoekvorm teweeggebring word reeds 'n aansienlike verbetering in die resultate teweegbring. Hoe groter die mate van strukturering, gebaseer op die inhoud en spesifikasies van die pos waarvoor geselekteer word, hoe hoër die geldighede en betroubaarhede wat blykbaar met behulp van die onderhoud 
as voorspeller van werkskriteria behaal word (McMurray, 1947; Howell en Vincent, 1970 en Carlson, et al, 1971).

Dit wil dus voorkom asof goed gestruktureerde onderhoude wat deur opgeleide onderhoudvoerders behartig word, tot ' $n$ groot mate die voordele verbonde aan deeglik beplande aansoekvorms en biografiese vraelyste deel. In die verband laat Miner en Miner (1973 p.278) hul as volg uit: "It is evident that the interview can be quite effective when used in a relatively standardized manner and when individualized interviewer approaches and biases are controlled. Under such standardized conditions the interview takes on certain characteristics of the application blank or a psychological test. It becomes in many respects an oral version of the common written selection procedures although still with greater flexibility".

Daar is ' $\mathrm{n}$ groter waarskynlikheid dat vooroordele en algemene "kleuring" van inligting en subjektiewe beoordeling in onderhoudvoering sal bestaan hoe minder gestruktureerd die onderhoud is, daar die aandeel van die "subjektiewe mensfaktor" groter is. Deur van 'n meer gesofistikeerde vooraf gestruktureerde onderhoudbenadering gebruik te maak, sal 'n groter mate van standaardisasie in die hand gewerk word. Die blote feit dat soortgelyke inligting op dieselfde stadium en in dieselfde volgorde in die onderhoud ingewin word, sal reeds die betroubaarheid en geldigheid van die onderhoud bevorder (Asher, 1970). 'n Meer objektiewe benadering word so gebruik wat sal verseker dat dieselfde gewig aan positiewe en negatiewe (gunstige en ongunstige) inligting geheg word.

Die skrywer is van mening dat dieselfde inligting wat met behulp van die gepatroneerde onderhoudbenadering geïn word, ook in 'n groot mate met behulp van die biodata-vraelysbenadering ingewin kan word. Met ander woorde dat 'n goed beplande werkgeoriënteerde biografiese-vraelys die tradisionele onderhoud grootliks kan vervang. Die grootste voordeel wat moontlik deur ' $n$ totale uitskakeling van die onderhoudvoerder ingeboet word, is die buigbaarheidskenmerk van die onderhoud. Dit sal egter nie noodwendig nodig wees om die tradisionele onderhoud heeltemal te elimineer nie, maar om net die belangrikheid daarvan (die afhanklikheid daarvan as voorspeller) te verminder en 'n meer betroubare objektiewe tegniek wat bykans dieselfde funksie vervul, in te span.

- Deur die inligtingsinwinningsfase van die beoordelingsfase te skei, word die betroubaarheid van die onderhoud geweldig verbeter. (Grant en Bray, 1969, p. 28). Die akkuraatheid van die beoordeling kan verbeter word deur eers 'n opname wat van die onderhoud gemaak is, deur te lees of deur te luister (Maier en Thurber, 1968). Dit mag wees dat 
die teenwoordigheid van die applikant daartoe bydra dat die konsentrasie van die onderhoudvoerder op wat werklik gesê word, verminder.

Asher (1970) se navorsing sluit baie goed hierby aan. Hy het bevind dat onderhoude wat op video-band opgeneem is, lei tot dieselfde graad van betroubaarheid aan die kant van die onderhoudvoerder as inligting wat op oudio-band alleen opgeneem is.

- $\quad$ Relatief goeie geldighede word verkry deur van meer as een beoordelaar gebruik te maak. Deur die kandidaat van een onderhoudvoerder na 'n ander te laat gaan en later 'n gesamentlike beoordeling van die onderhoudvoerders te kry of om van 'n paneel takseerders (onderhoudvoerders) gebruik te maak, word beter resultate gelewer (Mayfield, 1964).

\section{GEVOLGTREKKING}

Opsommend kan dus gesê word dat die geldigheid van die tradisionele indiensnemingsonderhoud om toekomstige werksgedrag te kan voorspel, nog nie afdoende bewys is nie. Nadat Mayfield (1964) meer as driehonderd artikels ondersoek het, is hy nog steeds krities ten opsigte van die geldigheid van onderhoude. Die gewone seleksieonderhoud lewer sulke lae geldigheids- en betroubaarheidskoëffisiënte dat baie skrywers al voorgestel het dat dit uit die seleksieprosedure verwyder word (England en Paterson, 1960 en Dunnette, 1962). Die bruikbaarheid van die onderhoud as voorspeller in die seleksiesituasie kan egter bevorder word deur die onderhoud te struktureer, onderhoudvoerders op te lei, van meer as een beoordelaar gebruik te maak, die beoordelingsfase te skei van die inligtingsinwinnings-fase, en om van die verskillende ander bevindings op die gebied daarop van toepassing te maak.

Die skrywer is van mening dat die "subjektiewe" indiensnemingsonderhoud as 'n basiese onderdeel van die seleksieprosedure behou kan word, maar dat die relatiewe belangrikheid daarvan vir die seleksiebesluit ten gunste van goed ontwikkelde gestruktureerde vraelyste soortgelyk aan gesofistikeerde biografiese-vraelyste verminder moet word.

\section{OPSOMMING}

'n Oorsig van navorsingsbevindinge op die gebied van die onderhoud word sistematies weergegee en na aanbieding daarvan word tot ' $n$ paar gevolgtrekkings gekom en aanbevelings gemaak. 


\section{VERWYSINGS}

Asher, J.J. Reliability of a Novel Format for the Selection Interview. Psychological Reports. 1970, 26, 451-456 (a).

Asher, J.J. How the Applicants' Appearance Affects the Reliability and Validity of the Interview. Educational and Psychological Measurement. 1970, 30, 687-695 (b).

Beach, D.S. Personnel. Derde Uitgawe, New York: MacMillian, 1975.

Carlson, R.E. Selection Interview Decisions: The Relative Influence of Appearance and Factual Information on an Interviewer's Final Rating. Journal of Applied Psychology. 1967, 51, 461-468.

Carlson, R.E.; Schwab, D.P. en Heneman, H.G. Agreement Among Styles of Selection Interviewing. Journal of Industrial Psychology, 1970, 5, 8-17.

Carlson, R.E.; Thayer, P.W.; Mayfield, E.C. en Peterson, D.A. Improvement in the Selection Interview. Personnel Journal, 1971, 50, 268-275, 317.

Carroll, S.J. Beauty, Bias and Business. Personnel Administration, 1969, 32, 21-25.

Dunnette, M.D. Personnel Management. Annual Review of Psychology, 1962, 13, 285-314.

England, G.W. en Paterson, D.G. Selection and Placement - The past ten years. New York: Harper, 1960, 43-72.

Flippo, E.B. Principles of Personnel Management. Derde Uitgawe, MacGraw-Hill, 1971.

Grant, D.L. en Bray, D.W. Contributions of the Interview to Assessment of Management Potential. Journal of Applied Psychology, 1969, 55, 1, 26-29.

Hakel, M.D.; Dobmeyer, T.W. en Dunnette, M.D. Relative Importance of Three Content Dimensions in Overall Suitability Ratings of Job Applicants' Resumes. Journal of Applied Psychology, 1970, 54, 65-71.

Hakel, M.D. en Dunnette, M.M. Interpersonal Perception in the Employment Interview. Industrial Psychology, 1968, 5, 30-38.

Hakel, M.D.; Dollmann, T.D. en Dunnette, M.D. Accuracy of Interviewers' , C.P.A.'s and Students in Identifying the Interests of Accountants. Journal of Applied Psychology, 1970, 54, 115-119.

Hakel, M.D.; Olinesarge, J.P. en Dunnette, M.D. Interviewer Evaluations of Job Applicants' Resumes as a Function of the Qualifications of the Immediately Preceding Applicants. Journal of Applied Psychology, 1970, 54, 27-30.

Hollingworth, H.L. Judging Human Character. New York: Appleton, 1922.

Hollman, T.D. Employment Interviewers' Errors in Processing Positive and Negative Information. Journal of Applied Psychology, 1972, 56, 130-134.

Howell, M.A. en Vincent, J.W. Factor Analysis of Interview data. Journal of Applied Psychology, 1970, 54, 313-315.

Langdale, J.A. en Weitz, J. Estimating the Influence of Job Information on Interviewer Agreement. Journal of Applied Psychology, 1973, 57, 23-27.

Maier, N.R.F. en Thurber, J.A. Accuracy of Judgement of Deception where an Interview is Watched, heard and read. Personnel Psychology, 1968, 21, 23-30.

Mayfield, E.C. The Selection Interview: A Re-Evaluation of Published Research. Personnel Psychology, 1964, 17, 239-260.

Mayfield, E.C. en Carlson, R.E. Selection Interview Decisions: First Results from a Longterm Research Project. Personnel Psychology, 1966, 18, 41-55.

McMurray, R.N. Validating the Patterned Interview. Personnel, 1947, 23, 263-272.

Miner, J.B. en Miner, M.G. Personnel and Industrial Relations - A Managerial Approach. 2de Uitgawe, New York: MacMillan, 1923.

Rowe, P.M. Individual Differences in Selection Decisions. Journal of Applied Psychology, 1963, 47, 304-307. 
Schwab, D.P. en Heneman, H.G. Relationship Between Interview Structure and Interviewer Reliability in an Employment Situation. Journal of Applied Psychology, 1969, 53, 214217.

Trites, D.K. Adaptability Measures as Measures of Performance Ratings. Journal of Applied Psychology, 1960, 44, 349-353.

Ulrich, L. en Trumbo, D. The Selection Interview Since 1949. Psychological Bulletin, 1965, 63, 100-116.

Valenzi, E. en Andrews, I.R. Individual Differences in the Decision Process of Employment Interviews. Journal of Applied Psychology, 1973, 58, 49-53.

Wagner, R. The Employment Interview: A Critical Summary. Personnel Psychology, 1949, 2, 17-46.

Webster, E.C. Decision Making in the Employment Interview. Montreal: Industrial Relations Center, McGill University, 1964.

Wexley, R.N.; Yukl, G.A.; Kovaco, S.Z. en Sanders, R.E. Importance of Contrast Effects in Employment Interviews. Journal of Applied Psychology, 1972, 56, 45-48.

Wright, O.R. Summary of Research on the Selection Interview Since 1964. Personnel Psychology, 1969, 22, 391-413. 